\title{
Technological innovations in silage production and utilization ${ }^{1}$
}

\author{
Inovações tecnológicas na produção e uso da silagem
}

\author{
BERNARDES, Thiago Fernandes ${ }^{2 *}$; CHIZZOTTI, Fernanda Helena Martins ${ }^{3}$
}

\author{
${ }^{1}$ Revisão apresentada no Congresso Brasileiro de Zootecnia (ZOOTEC 2011). \\ ${ }^{2}$ Universidade Federal de Lavras, Departamento de Zootecnia, Lavras, Minas Gerais, Brasil. \\ ${ }^{3}$ Universidade Federal de Viçosa, Departamento de Zootecnia, Viçosa, Minas Gerais, Brasil. \\ *Endereço para correspondência: thiagobernardes@dzo.ufla.br
}

\section{SUMMARY}

Technology innovation is the process through which new technologies are developed. Silage research addresses the various agronomical, biochemical, microbiological, nutritional and engineering aspects of the process. Forage harvesters, additives (inoculants), and plastic films for sealing are important recent developments. The corn silage is the major source of energy in rations, but recently the use of other ensiled crops, such as sugarcane and legumes, has been increased. Two newer ensiling techniques are the pressed bag and the wrapped bale. Polyethylene film has been the most common method used to protect silage near the surface, but new plastic films are available or in the process of development. A co-extruded polyethylene-polyamide film and new polyvinyl alcohol film also have been used to seal corn silage. Various types of additives have been developed in order to improve the ensiling process. Lactobacillus buchneri, that is an obligate heterolactic acid bacterium, might improve the aerobic stability of silages and have been more effective in corn silage than in other silages. Energy production from silage has also attracted much interest in recent years, as perennial grasses that have been stored as biomass to produce biofuels in the United States, and silage as feedstock for biogas in Europe.

Keywords: bioenergy, ensiling, film cover, inoculant, management practices, silo.

\section{RESUMO}

Inovação tecnológica é o processo que representa o desenvolvimento de novas tecnologias e o aperfeiçoamento das já existentes. A pesquisa referente à silagem envolve vários aspectos agronômicos, bioquímicos, microbiológicos, nutricionais e a engenharia do processo. Colhedoras de forragem, inoculantes e filmes plásticos para a vedação do silo são importantes e recentes desenvolvimentos. A silagem de milho é a principal fonte de energia em rações, mas, atualmente, o uso de outras forrageiras, tais como cana-de-açúcar e leguminosas tem sido incrementado. Duas técnicas de ensilagem são consideradas inovadoras: estocagem em silos tubulares horizontais e silos/fardos revestidos por filme plásticos. Quanto à vedação de silos trincheira ou superfície, o filme de polietileno tem sido o método mais comumente utilizado para proteger a silagem próxima da superficie, porém novos filmes já estão disponíveis ou em processo de desenvolvimento. $O$ filme coextruzado de polietileno/poliamida e o novo filme de polivinil álcool são, recorrentemente, utilizados para cobrir a silagem. Diversos tipos de aditivos são desenvolvidos, na atualidade, com o intuito de melhorar o processo de ensilagem. Lactobacilus buchneri, uma bactéria heterolática obrigatória, pode melhorar a estabilidade aeróbia de silagens e, nos tempos vigentes, é mais efetiva na preservação da silagem de milho do que em outras. A produção de energia a partir de silagem tem despertado o interesse nos últimos anos. Como fruto desse crescente interesse gramíneas perenes tem sido estocadas como biomassa para produzir biocombustíveis nos Estados Unidos, e silagem tem sido utilizada como matéria prima para produção de biogás na Europa.

Palavras-chave: bioenergia, ensilagem, inoculante, lona, práticas de manejo, silo. 


\section{INTRODUCTION}

Technology innovation is the process through which new (or improved) technologies are developed and brought into widespread use. In the simplest formulation, innovation can be thought of as being composed of research, development, and deployment.

Silage research addresses the various agronomical, biochemical, microbiological, nutritional and engineering aspects of the process. Much of silage research is performed

to understand the complex processes that take place during ensiling in order to gain better control and higher quality of the preserved feed.

In the last years, several trends in silage research are notable because most innovations are driven by private companies. Forage harvesters, additives (inoculants), and plastic films for sealing are important recent developments.

Although there are many technological innovations available the gaps between "proven technology" and "real efficiency" of silage programs in Brazilian farms too often are too wide, especially in low input systems due to modest resource availability, the subsistence-farming goal, and the low productivity of the native livestock. Therefore, most technological innovations are restricted to developed countries and Brazilian farms with high input systems because ensiling is a sophisticated and costly operation.

In the forage conservation area, technology innovations have helped farmers to improve silage quality for ruminant throughout the year. However studies are still needed to: understand the processes affecting quality during harvest and storage and develop practical means to reduce losses and enhance quality.
Energy production from silage has also attracted much interest in recent years. In the United States, perennial grasses have been stored as biomass to produce biofuels. Silage as feedstock for biogas has been a trend in Europe.

In this paper, we hope to briefly summarize recent developments involved in the production, storage and utilization of silage and to highlight areas of research that we believe are most important.

\section{SILAGE CROPS}

Traditionally in many parts of Europe, Northern and Southern America corn silage is the major source of energy in rations. Major developments, both in plant breeding and in agronomic practices, have enabled consistent production of high yields of this crop.

In last years there has been increasing interest by different seed companies to develop corn hybrids specifically proposed for silage making. Hybrid selection is a critical step for profitable production of corn silage, since silage yield and quality can vary greatly among hybrids. Traditionally, hybrids with the highest grain yield have been chosen for both grain and silage purposes. However, since corn silage is an energy source for animal performance, producers should evaluate both silage yield and quality when selecting hybrids. Therefore, selection of silage hybrids for forage yield also is necessary because there is considerable variation in yield and digestibility of the nongrain (stover) fraction across hybrids. Plant modifications have been made through traditional breeding and/or biotechnology to accomplish some of these goals toward ideal corn silage. High-quality corn silage hybrids have been obtained through genetic selection 
for improved stover digestibility and grain yield (CRAIG, 2010).

The maturity of corn is one of the most important things to consider when selecting hybrids, and if missed can invalidate the benefits of good hybrid selection since harvesting at the right moisture level is essential for producing high quality silage.

Some quality traits affect diet cost, while others also affect feed intake and milk yield. Selection indices, such as "Milk per Acre "and" Milk/ton, which are calculated using the software MILK2006 spreadsheet developed at the University of Wisconsin, have been developed to combine yield and quality factors respectively into one term to simplify hybrid ranking (SHAVER et al., 2006). According to Craig (2010) agronomic traits under development or future possibilities for development in corn for silage include: drought tolerance, cold tolerance, disease tolerance, insectstalk snap resistant for less field loss; increased grain to stover ratio; slower grain drydown, and mycotoxin resistance. The corn hybrid selection for silage should be done carefully about to manage risk and to maximize silage quality, yield and overall economic return.

In recent times, other ensiled forages, such as sugarcane and legumes have increased in popularity and have partially replaced corn silage in the diet. Recently, the interest for the use of legume silage in animal feeding system has been studied in several countries, being that, in Brazil, the soybean silage (Glycine $\max$ L. Merrill) has been of bigger interest (PEREIRA et al., 2009).

Sugarcane (Saccharum officinarum L.) is an important crop in Asia, Africa and Latin America. The potential of sugarcane as a feedstuff for ruminants in tropical and subtropical areas is not new. However the area used of sugarcane for ethanol production in Brazil shows growth. With the technological development promoted by the agricultural sector livestock farmers began to use it like roughage. According to Millen et al. (2009) fresh chopped sugarcane is the primary roughage source offered to beef cattle in Brazil. Popularization of sugarcane among Brazilian farmers is due to studies that search for solutions to enhance the use of this forage. Among recent progresses, is the use of additives to reduce losses in the sugarcane ensiling process (SIQUEIRA et al., 2007).

\section{SILO TYPES}

Livestock farms can store silage in various ways such as horizontal silos (bunker and stacks), tower silos, bagged silos, or large wrapped bales. While silage can be made successfully in all, each type has specific management issues needing investigation.

The most common silos around the world are horizontal piles with or without walls. Several farms prefer horizontal silos due to relatively low construction costs, greater safety compared to tower silos (no toxic gases produced in closed areas, low risk of fall) and high work rates for filling and unloading. Few significant changes have occurred in silo design with the exception of systems for the collection of effluent being required in many

countries where low dry matter crops are ensiled. Silage effluent is corrosive to concrete and recent work indicates that some formulations of asphaltic concrete and mastic asphalt are corroded at less than onefourth the rate of standard concrete formulations (WEYDERT et al., 2001). In the southern Minas Gerais (Brazil) some dairy farms are using asphalt in coating of the silos, but no experimental results so far. 
Tower silos are much less common and are primarily found in the northern U.S. and

Canada. While these silos are excellent for preserving a crop, they have fallen in usage (the most expensive).

A newer ensiling technique is the pressed bag. Crops are pressed into polyethylene tubes that typically range in diameter from 1.8 to $3.6 \mathrm{~m}$ and lengths of 30,60 and $90 \mathrm{~m}$. This silo type appears to be growing rapidly due to low cost, ability to segregate forages by quality, and flexibility of storage capacity. However, little research has been reported on the performance of these silos. Research on densities and dry matter (DM) losses in these silos and the factors that affect both is needed.

Another newer method of making silage is the wrapped bale. It is popular in Europe and provides the farmer with considerable flexibility in terms of harvesting and feeding. In Brazil, wrapped bale is very common in Paraná State, particularly on dairy farms. In many instances, growing the silage crop and harvesting the crop are done completely on a contract basis. Several wrapping systems are available: stretch wrap plastic on individual round and rectangular bales or large round bales arranged end to end and either placed in a plastic tube or wrapped with stretch wrap (SAVOIE \& JOFRIET, 2003). These latter alternatives reduce the plastic used, greatly increase the wrapping productivity and reduce the storage space compared to individually wrapped bales. However, tubeline wrapping can reduce feeding flexibility compared to individual wrapping. Research on baled silage has sensibly been focused on the creation and maintenance of anaerobic conditions. In particular the stretch film applied to bales and its effect on the preservation of silage has been the subject of much study (BORREANI \& TABACCO, 2010).

\section{SOFTWARE APPLICATIONS FOR SIZING AND MANAGING SILOS}

Bunker and stack silo sizing and management can benefit from many mathematical calculations to consider some of the "What if?" scenarios (HOLMES, 2009). Multiple calculations using the same set of equations can benefit from the use of computer software. Many software packages have been developed in spreadsheet format and are available for download from the Harvest and Storage page of the University of Wisconsin-Extension Team Forage web site located at URL: www.uwex.edu/ces/crops/uwforage/stor age.htm.

\section{HARVESTING SILAGE CROPS}

In many countries, farm sizes are increasing. Also because of the high cost of farm machinery, contracted operations are becoming more common. As a consequence, there is a trend toward larger and self-propelled forage harvesters. Self-propelled forage harvesters have three to four times the capacity of a pull-type harvester so the shift to self-propelled machines has dramatically reduced the total unit sales of harvesters. Worldwide sales of pulltype harvesters have diminished from about 7,000 to 4,000 to 3,500 in 1990 , 1995 and 2000, respectively, whereas sales of self-propelled harvesters have increased from about 1,800 to 2,200 to 2,500 over the same period (MUCK \& O'KIELY, 2002). Although on Brazilian 
farms pull-type harvester is still more common.

Larger equipment helps to harvest forage in a more timely fashion, providing forage of a more uniform and higher quality. On the other hand, equipment at the silo must be sized to adequately handle the increased rate of forage received. This is especially critical in bunker or stack silos where high densities are dependent on good packing practices. Increasing the rate of forage coming to the bunker silo without change packing practices will decrease packing time per unit crop and thus reduce density (HOLMES \& BOLSEN, 2009).

Kernel or crop processing has been a common feature on forage harvesters for making corn and sorghum silages. It is most commonly performed by passing the chopped crop between two counter-rotating rolls set 1 to $5 \mathrm{~mm}$ apart and operating at differential speeds (SHINNERS, 2003). The purpose is to break open kernels and abrade or shred the cob into small pieces to improve kernel and starch digestion.

Another area of change in forage harvesting equipment is in the area of monitoring yield and quality (SAVOIE $\&$ SHINNERS, 2009). The goal is to bring forage harvesting up to a similar level of sophistication as grain harvesting. Forages could be more accurately separated at harvest by quality and placed in different silos.

Wrapped bales as indicated earlier have become a common means of making silage in some countries. The low density and long particles have resulted in a number of advances in bale silage technology. Cutting systems were introduced about 20 years ago on round balers to coarsely chop the forage (SHINNERS, 2003). Initially the theoretical lengths of cut (TLCs) were 75 to $100 \mathrm{~mm}$. Today systems are available that provide TLCs of 20 to $50 \mathrm{~mm}$ for both round and square balers. These cutting systems improve density, fermentation and feed handling issues (BORREANI \& TABACCO, 2006).

\section{FILLING AND PACKING}

Technology development has been small in this area than to others ensiling phases. The conventional machine used for spreading and packing the forage in horizontal silos is the agricultural tractor with four wheel drive (WEINBERG \& ASHBELL, 2003). Some producers have experimented with alternative packing vehicles. Industrial wheel loaders are heavier than agricultural tractors on an equivalent power basis. They are often used for silage feed-out from bunker and stack silos. This makes them prime candidates for alternative packing vehicles. The tires on industrial loaders are not as well lugged as farm tractors, which allow them to slide more easily on sloped forage surfaces. This makes the operators very uncomfortable about their safety while packing (HOLMES \& BOLSEN, 2009). Tracked industrial bulldozers have been tried by some producers. The naturally heavy weight and some vibration can contribute to good packing. There have been few studies on the effect of bulldozers on silage density. Tracked vehicles are likely more stable on wet sloped surfaces than wheel loaders (HOLMES \& BOLSEN, 2009).

A high density is desirable because air infiltration is limited, oxidation loss during storage and feed-out is reduced, more DM is stored in the same volume and the fixed costs of storage per unit dry matter are reduced (JOHNSON et al., 2002). 
Previously, recommendations for packing in horizontal silos have been based on DM density. However, DM density does not account for porosity. Porosity is a measure of the voids between the solid particles of a material. Pore space can be filled with fluids, including gas and/or water in silage. The "air filled" porosity allows gases to move within the material. For gases to move throughout the material, the pores must be continuous. Closed pores do not contribute to gas flow.

Porosity is most influenced by bulk density (fresh weight density) over the range of DM contents recommended for ensiling in bunkers, stacks, and bags. Bulk density in silage is affected by the same packing practices as DM density: tractor weight, packing time and spreading layer thickness as well as depth of silage; however, the same packing practices result in a lower bulk density as DM content increases. This trend is the opposite of what occurs with DM density. As forage becomes drier, the porosity increases for the same DM density. Higher porosity allows for increased oxygen infiltration rate with consequent increased DM loss due to aerobic deterioration (HOLMES, 2009).

Thus, Holmes (2009) recommended a minimum bulk density of $705 \mathrm{~kg} / \mathrm{m}^{3}$ and a maximum porosity of 0.40 as a goal when packing forage in horizontal silos. To reach these goals, forage DM at harvest needs to be in the recommended range of 30 to $40 \%$ and packing effort needs to be adequate. If forage DM exceeds $40 \%$, packing effort needs to be much higher to produce high bulk density and to keep porosity at or below the 0.40 target.

\section{SEALING}

Minimization of aerobic silage losses primarily depends on the quality of the plastic film used to seal the silo or bag or bale, how tightly the plastic is held to the crop, how susceptible it is to damage, and how quickly the farmer notices damage and repairs it (BERNARDES et al., 2012).

Polyethylene film has been the most common method used to protect silage near the surface, but it is not perfect solution. It is permeable to oxygen and is not readily biodegradable. The ideal solution would be a replacement for polyethylene that could be applied easily and would be edible. Farmers and scientists have tried various solutions: grain, lime, molasses, and molassesbased products. These are better than no cover but are significantly less effective than polyethylene (MUCK et al., 2003). While ideal solutions do not appear to be on the immediate horizon, new plastic films are available or in the process of development. A co-extruded polyethylene-polyamide film has been developed for covering horizontal silos (BORREANI et al., 2007) by Industria Plastica Monregalese (Mondovi, Italy). It is $125 \mu \mathrm{m}$ in thickness and comprises two outer layers of polyethylene with a central layer of polyamide (Silostop ${ }^{\circledR} 1$ 1step). The same company has also developed a $45 \mu \mathrm{m}$ non-UV-stabilized translucent barrier film (Silostop® 2step clear) with similar oxygen permeability characteristics as their Silostop 1-step. Usually, the Silostop 2step is used in combination with a protective tarpaulin, but in Brazil studies have been tested in combination with a polyethylene sheet showed excellent results.

Bernardes et al. (2012) evaluated the effectiveness of the Silostop 1-step and 
the major plastic films used in Brazil to reduce the top losses in corn silage, which have different potential silage spoilage risks due to their permeabilities to oxygen. The authors reported that the Silostop 1-step showed a further improvement on DM recovery, sustaining its use in warm climates. Acceptable silage quality was also obtained using the new polyvinyl alcohol film to seal corn silage. The results also indicated that oxygen permeability through the plastic film is crucial factor for maintaining silage quality in the upper layer of the silo when it is perfectly sealed.

Regarding baled silage system, Borreani \& Tabacco (2010) studied the fermentation quality of alfalfa wrapped with polyethylene, polyethylene polyamide, and polyethylene-ethylene vinyl alcohol films and also concluded that reduced film permeability to oxygen, due to the use of polyamide and ethylene vinyl alcohol, is a key factor in successfully ensiling alfalfa in bales.

\section{UNLOADING AND FEEDING}

Losses during unloading and feeding depend on the duration of the exposure of the silage to air, the ambient temperature and the aerobic stability of the silage. Since air ingress into the silage from the unloading face depends on the silage density, the consolidation of the silage should be maintained during unloading, and the technology used for unloading affects this factor to a great extent (WEINBERG \& ASHBELL, 2003). Industrial wheel loaders remove silage quickly from the silo but offers a ragged face and may lift up seams for air to penetrate deeply into the silage (MUCK et al., 2003). Mechanization-based research has focused silage scraper (Block cutters) with vertical or horizontal mixing wagon which leave a smooth and less porous face. For most farmers, the attractions of total mixed ration (TMR) feeding systems are associated with management and labor saving aspects. The ability to remove, weigh, mix and accurately dispense feed-stuffs is particularly beneficial where a variety of feeds are to be fed including combinations of forages (i.e., corn and sugarcane silage) or a number of concentrate feed components.

\section{SILAGE ADDITIVES}

Especially in warm climates wholecrop cereal silages such sorghum and corn are susceptible to aerobic deterioration. This is because aerobic yeasts are most active at 20 to $30^{\circ} \mathrm{C}$ (ASHBELL et al., 2002). Therefore, efforts are being made to find suitable additives that would inhibit fungi and protect the silage upon exposure to air (BORREANI et al., 2008). In order to improve the ensiling process, various types of additives have been developed. The biological additives are advantageous because they are safe and easy to use, noncorrosive to machinery, do not pollute the environment, and are natural products (FILYA, 2003). Inoculants could be added to silage in order to stimulate lactic acid fermentation and to accelerate the drop in $\mathrm{pH}$. Most available inoculants consist of selected strains of homofermentative LAB strains, such as Lactobacillus plantarum, Enterococcus faecium and Pediococcus species, which could produce great quantity of lactic acid in a short time and so stabilize the silage with minimal losses. However, these homofermentative LAB strains enhance aerobic deterioration of wholecrop cereal silages, probably because 
not enough volatile fatty acids are produced to inhibit yeasts and molds (WEINBERG et al., 1993). Driehuis et al. (1996) were the first to suggest that inoculation with Lactobacillus buchneri, that is an obligate heterolactic acid bacterium, might improve the aerobic stability of silages. Since that time, Lactobacillus buchneri has been used as a silage inoculant to enhance the aerobic stability in a variety of silages via the anaerobic degradation of lactic acid to acetic acid. Kleinschmit \& Kung (2006) summarized the results of adding Lactobacillus buchneri to silages from 26 experiments on corn and two on sorghum silages. The inoculation treatments were classified into the following categories: untreated silage with nothing applied (LB0), silage treated with $\mathrm{L}$. buchneri at $\leq 1 \mathrm{x}$ $10^{5} \mathrm{cfu} / \mathrm{g}$ of fresh forage (LB1), and 3) silage treated with $\mathrm{L}$. buchneri at $>1 \mathrm{x}$ $10^{5} \mathrm{cfu} / \mathrm{g}$ (LB2). In both types of crops, inoculation with $L$. buchneri decreased concentrations of lactic acid, and in corn this response was dose-dependent. Treatment with L. buchneri markedly increased the concentrations of acetic acid in a dose-dependent manner. The numbers of yeasts were lower in silages treated with LB1 and further decreased in silages treated with LB2 compared with untreated silages. Untreated corn silage spoiled after $25 \mathrm{~h}$ of exposure to air but corn silage treated with LB1 did not spoil until $35 \mathrm{~h}$, and this stability was further enhanced to $503 \mathrm{~h}$ with LB2. Concerns that high concentrations of acetic acid in silages treated with $L$. buchneri may depress intake could not be addressed by the meta-analysis because of the low number of studies. However, available research has shown that when cattle (DRIEHUIS et al., 1999; TAYLOR et al., 2002) and sheep (RANJIT et al., 2002) are fed silages treated with L. buchneri, DM intake is not affected. The recovery of DM after ensiling was lower for LB2 $(94.5 \%)$ when compared with LB0 and LB1 $(95.5 \%)$ in corn silage. Kleinschmit \& Kung (2006) concluded their review stating that the higher rate of inoculation with L. buchneri was more consistently effective in corn silages than in grass and small-grain silages.

\section{SAFETY IN THE FOOD CHAIN}

Lindgren et al. (2003) proposed that food safety should cover the entire food chain from primary production to the consumer and that the chain includes forage production, especially silages. Food pathogens such as enterohaemorrhagic Escherichia coli (O157:H7), Listeria, Salmonella and Campylobacter have received considerable attention and Hazard Analysis and Critical Control Point (HACCP) principles have been developed and applied to assist in the control of pathogens from the point of presentation of livestock (PEDROSO et al., 2010).

Recently, Vissers et al. (2006, 2007) have emphasized the role of aerobic deterioration in corn silage at a farm level in relation to the presence of high concentrations of Clostridium and Bacillus spores in milk.

Spoilage of silages by molds involves nutrient and energy losses and the risk of contamination by mycotoxins. Identifying the conditions for mycotoxins production in relation to silage conservation techniques could help in developing strategies for restriction of toxin and moulds contamination and allow effective management of the problem (BORREANI et al., 2008). The International Agency for Research on Cancer includes aflatoxins among the 
substances that are carcinogenic for humans. The European Community has established that maximum levels of $\mathrm{AFM}_{1}$ in milk should not exceed 50ppt, in order to prevent higher concentration than 500ppt when milk was processed to cheese.

\section{ENVIRONMENTAL CONSTRAINTS}

Silage storage systems present a number of environmental challenges. While effluent production and control systems are understood, the post-use fate of the large quantities of plastic film used with baled and conventional silage is of concern (FORRISTAL \& O'KIELY, 2005). The baled silage system uses considerably more plastic at $5.5 \mathrm{~kg} / \mathrm{t} \mathrm{DM}$ than horizontal silos at $1.3 \mathrm{~kg} / \mathrm{t} \mathrm{DM}$ (SAVOIE, 1988). Collection and recycling systems are effective but the current systems may not be the most effective means of handling used films.

The use of biodegradable film has been considered. Borreani et al. (2010) studied two different silage cover films, one made of polyethylene and the other made biodegradable plastic. After 55 and $110 \mathrm{~d}$ of conservation, all the silages were well fermented with no differences in fermentative and nutritional quality between the treatments, and few differences in mould count and aerobic stability after $110 \mathrm{~d}$ of conservation. These results showed the possibility of successfully developing a biodegradable cover for silage for 4 months after ensiling.

\section{SILAGE FOR NON FORAGE USES}

Energy production from silage has also attracted much interest in recent years.
In North America, the main feedstock for fuel ethanol is currently corn grain. New enzyme hydrolysis and fermentation technologies are being developed to produce ethanol from cellulosic biomass such as grasses, straw, and wood (DIGMAN et al., 2010). Some perennial grasses such as reed canarygrass (Phalaris arundinacea L.) and switchgrass (Panicum virgatum L.), have prolific yield and low inputs, making them attractive as biomass feedstocks. Much is unknown about how harvest equipment performance and storage characteristics are affected by these crop conditions. Thus, studies are being developed using ensiling techniques, mainly those related to the bale and bale wrapping systems (SHINNERS et al., 2010).

In Europe, particularly in Germany, silages from different crops have been increasingly used as substrates for biogas production (WEISSBACH, 2009). The utilization of energy crops for biogas production yields similar limitations as those observed with forage digestibility. During the biogas process, biomass is converted through different steps into methane and carbon dioxide. Major intermediates are different acids mainly focused on acetic acid (RUSER, 2009). At the last International Silage Conference several trials investigated whether adjusting the fermentation pattern of silage, by using additives as a silage-starter, will result in an enhanced methane production in the biogas process.

The developments that have occurred over the past 15 years have really made silage an option for more farms, particularly in high input systems. Wrapped bale and pressed bag silage have created more flexibility in silage making and management, development of these systems is still occurring to help them produce more consistent 
silage and make them more efficient. We are also on the edge of a major change in harvesting, monitoring the characteristics of the crop as it is harvested. This will help farmers manage the ensiling of their crops more efficiently: knowing when to apply additives, more precisely controlling additive application rates, and separating crops by quality at harvest. Although polyethylene sheeting has been the most common method used to cover silage, new coextruded plastic films such as polyethylene/polyamide,

polyethylene/polyvinyl alcohol, and polyethylene/ethylene vinyl alcohol have resulted in an improvement in the silage quality and a reduction in the DM losses in the peripheral area of the silo.

\section{REFERENCES}

ASHBELL, G.; WEINBERG, Z.G.; HEN, Y.; FILYA, I. The effects of temperature on the aerobic stability of wheat and corn silages. Journal

Industrial Microbiology

Biotechnology, v.28, p.261-263, 2002.

BERNARDES, T.F.; NUSSIO, L.G.; AMARAL, R.C. Top spoilage losses in maize silage sealed with plastics films with different permeabilities to oxygen. Grass and Forage Science, v.67, p.3442, 2012.

BORREANI, G.; BERNARDES, T.F.; TABACCO, E. Aerobic deterioration influences the fermentative, microbiological and nutritional quality of maize and sorghum silages on farm in high quality milk and cheese production chains. Revista Brasileira de Zootecnia, v.37, p.68-77, 2008.
BORREANI, G.; CHION, A.R.; PIANO S.; RANGHINO, F.; TABACCO, E. A preliminary study on new biodegradable films to cover silages. In: XXIII GENERAL MEETING OF THE EUROPEAN GRASSLAND FEDERATION, 23., 2010, Kiel, Germany. Proceedings... Kiel, Germany, 2010. p.202.

BORREANI, G.; TABACCO, E. The effect of a baler chopping system on fermentation and losses of wrapped big bales of alfalfa. Agronomy Journal, v.98, p.1-7, 2006.

BORREANI, G.; TABACCO, E. Use of new plastic stretch films with enhanced oxygen impermeability to wrap baled alfalfa silage. Transactions of the ASABE, v.53, p.635-641, 2010.

BORREANI, G.; TABACCO, E.; CAVALLARIN, L. A new oxygen barrier film reduces aerobic deterioration in farm-scale corn silage. Journal of Dairy Science, v.90, p.4701-4706, 2007.

\section{CRAIG, D.L. Current and future} genetics in corn silage. Available: $<$ http://alfalfa.ucdavis.edu/+symposium/2 010/files/talks/CAS25_CraigCornGenetic s.pdf>. Accessed: 07 Mar. 2011.

DIGMAN, M.F.; SHINNERS, K.J; MUCK, R.E.; DIEN, B.S. Pilot scale on farm pretreatment of perennial grasses with dilute acid and alkali for fuel ethanol production. Transactions of the ASABE, v.53, p.1007-1014, 2010.

DRIEHUIS, F.; SPOELSTRA, S.F.; COLE, S.C.J. Improving aerobic stability by inoculation with Lactobacillus buchneri. In: INTERNATIONAL SILAGE CONFERENCE, 11., 1996, Aberystwyth. Proceedings... Aberystwyth, 1996. p.106-107. 
Rev. Bras. Saúde Prod. Anim., Salvador, v.13, n.3, p.629-641 jul./set., 2012 http://www.rbspa.ufba.br ISSN 15199940

DRIEHUIS, F.; OUDE ELFERINK, S.J.W.H.; SPOELSTRA, S.F.

Anaerobic lactic acid degradation during ensilage of whole crop maize inoculated with Lactobacillus buchneri inhibits yeast growth and improves aerobic stability. Journal of Applied Microbiology, v.87, p.583-594, 1999.

FILYA, I. The effect of Lactobacillus buchneri and Lactobacillus plantarum on the fermentation, aerobic stability, and ruminal degradability of low dry matter corn and sorghum silages.

Journal of Dairy Science, v.86, p.3575-3581, 2003.

FORRISTAL, P.D., O'KIELY, P. Update on technologies for producing and feeding silage. In:

INTERNATIONAL SILAGE CONFERENCE, 14., Belfast, Ireland, 2005. Proceedings... Belfast, Ireland, 2005, p.83-96.

HOLMES, B.J. Software applications for sizing silos to maximize silage quality. In: INTERNATIONAL SYMPOSIUM ON FORAGE QUALITY AND UTILISATION, Piracicaba. Proceedings... Piracicaba: FEALQ, 2009. p.189-208.

HOLMES, B.J; BOLSEN, K.K. What's new in silage management. In: INTERNATIONAL SILAGE CONFERENCE, 15., 2009, Madison, USA. Proceedings... Madison, USA, 2009. p.61-76.

JOHNSON, L.M.; HARRISON, J.H.; DAVIDSON, D.; MAHANNA, W.C.; SHINNERS, K.J.; LINDER, D. Corn silage management: Effects of maturity, inoculation, and mechanical processing on pack density and aerobic stability. Journal of Dairy Science, v.85, p.434444, 2002.
KLEINSCHMIT, D. H.; KUNG, JR, L. A meta-analysis of the effects of Lactobacillus buchneri on the fermentation and aerobic stability of corn and grass and small-grain silages.

Journal Dairy Science, v.89, p.40054013, 2006.

LINDGREN, S.E.; OLDENBURG, E.; PAHLOW, G. Influence of microbes and their metabolites on food and feed quality. In: EUROPEAN GRASSLAND FEDERATION, 19., 2003, La-Rochelle, France. Proceedings... La-Rochelle, France, 2003. p.503-511.

MILLEN, D.D.; PACHECO, R.D.L.; ARRIGONI, M.D.B.; GALYEAN, M.L.; VASCONCELOS, J.T. A snapshot of management practices and nutritional recommendations used by feedlot nutritionists in Brazil. Journal of Animal Science, v.87, p.3427-3439, 2009.

MUCK, R.E.; MOSER, L.E.; PITT, R.E. Postharvest plant factors affecting ensiling. In: BUXTON, D.R.; MUCK, R.E.; HARRISON, J.H. (Eds.). Silage Science and Technology. Madison: American Society of Agronomy, 2003. p.251-304.

MUCK, R.E.; O’KIELY, P. New technologies for ensiling. In:

INTERNATIONAL SILAGE CONFERENCE, 13., Auchincruive, Scotland, 2002. Proceedings... Auchincruive, Scotland, 2002. p.334-343.

PEDROSO, A.F.; ADESOGAN, A.T.; QUEIROZ, O.C.M.; WILLIAMS, S.K. Control of Escherichia coli O157:H7 in corn silage with or without various inoculants: Efficacy and mode of action. Journal of Dairy Science, v.93, p.10981104, 2010. 
Rev. Bras. Saúde Prod. Anim., Salvador, v.13, n.3, p.629-641 jul./set., 2012 http://www.rbspa.ufba.br ISSN 15199940

PEREIRA, O.G.; OLIVEIRA, A.S.; RIBEIRO, K.G. Strategies to enable the use of legume silage in ruminant production. In: INTERNATIONAL SYMPOSIUM ON FORAGE QUALITY AND UTILISATION, 2009, Piracicaba. Proceedings... Piracicaba: FEALQ, 2009. p.109-136.

SAVOIE, P. Optimization of plastic covers for stack silos. Journal Agricultural Engineering Research, v.41, p.65-73, 1988.

SAVOIE, P.; JOFRIET, J.C. Silage storage. In: Buxton, D.R.; Muck, R.E.; Harrison, J.H. (Eds.). Silage Science and Technology. Madison: American Society of Agronomy, 2003. p.405-468.

SAVOIE, P.; SHINNERS, K.J. Advances in silage harvesting. In: INTERNATIONAL SILAGE CONFERENCE, 15., 2009, Madison, USA. Proceedings... Madison, USA, 2009. p.169-180.

SHAVER, R.; LAUER, J.; COORS, J.; HOFFMAN, P. Milk 2006 Excel spreadsheet. Available: $<$ www.uwex.edu/ces/crops/uwforage/de c_soft.htm>. Accessed: 07 Mar. 2011.

SHINNERS, K.J; BOETTCHER, G.C.; MUCK, R.E.; WEIMER, P.J.;

CASLER, M.D. Harvest and storage of two perennial grasses as biomass feedstock. Transactions of the ASABE, v.53, p.359-370, 2010.

SHINNERS, K.J. Engineering principles of silage harvesting equipament. In: BUXTON, D.R.; MUCK, R.E.; HARRISON, J.H. (Eds.). Silage Science and Technology. Madison: American Society of Agronomy, 2003. p.361-404.
SIQUEIRA, G.R.; REIS, R.A.; SCHOCKEN-ITURRINO, R.P.; BERNARDES, T.F.; PIRES, A.J.V.; ROTH, M.T.P.; ROTH, A.T.P. Chemical and bacterial additives association on the sugar cane ensilage. Revista Brasileira de Zootecnia, v.36, p.789-798, 2007.

RANJIT, N.K.; TAYLOR, C.C.; KUNG JÚNIOR, L. Effect of Lactobacillus buchneri 40788 on the fermentation, aerobic stability and nutritive value of maize silage. Grass and Forage Science, v.57, p.73-81, 2002.

RUSER, P.; PAHLOW, G.; KRÄFT, A.; RUTHERFORD, A. Improved biogas production from silage treated with an esterase producing inoculant. Prediction of biogas production potential of silages. In: INTERNATIONAL SILAGE CONFERENCE, 15., 2009, Madison, USA. Proceedings... Madison, USA, 2009. p. 455-456.

TAYLOR, C.C.; RANJIT, N.J.; MILLS, J.A.; NEYLON, J.M.; KUNG, JÚNIOR L. The effect of treating whole-plant barley with Lactobacillus buchneri 40788 on silage fermentation, aerobic stability, and nutritive value for dairy cows.

Journal of Dairy Science, v.85, p.17931800, 2002.

VISSERS, M.M.M.; DRIEHUIS, F.; TE GIFFEL, M.C.; DE JONG, P.; LANKVELD, J.M.G. Minimizing the level of butyric acid bacteria spores in farm tank milk. Journal of Dairy Science, v.90, p.3278-3285, 2006.

VISSERS, M.M.M.; DRIEHUIS, F.; TE GIFFEL, M.C.; DE JONG, P.;

LANKVELD, J.M.G. Concentrations of butyric acid bacteria spores in silage and relationships with aerobic deterioration. Journal of Dairy Science, v.90, p.928936, 2007. 
Rev. Bras. Saúde Prod. Anim., Salvador, v.13, n.3, p.629-641 jul./set., 2012 http://www.rbspa.ufba.br ISSN 15199940

WEINBERG, Z.G.; ASHBELL, G. Engineering aspects of ensiling. Biochemical Engineering Journal, v.13, p.181-188, 2003.

WEINBERG, Z.G.; ASHBELL, G.; HEN, Y.; AZRIELI, A. The effect of applying lactic acid bacteria at ensiling on the aerobic stability of silages.

Journal of Applied Bacteriology, v.75, p.512-518, 1993.

WEISSBACH, F. Prediction of biogas production potential of silages. In: INTERNATIONAL SILAGE CONFERENCE, 15., 2009, Madison, USA. Proceedings... Madison, USA, 2009. p.189-190.
WEYDERT, M.; VAN CAENEGEM, L.; DEHON, P. Resistance of concrete, asphaltic concrete and mastic asphalt to silage juice. Journal of Agricultural Engineering Research, v.79, p.151157, 2001.

Data de recebimento: 10/11/2011

Data de aprovação: 10/05/2012 